\title{
脛骨骨幹部骨折に対して観血的整復を行った䯣内釘手術の治療成績
}

\author{
櫻 井 真* 尾上 英 俊* 白 地仁* \\ 田中潤*轟 木 将 也*亀川史 武*
}

\section{Clinical Results of Intramedullary Nailing in Open Reduction of Tibial Shaft Fractures}

\author{
Makoto Sakurai*, Hidetoshi Onoue*, Hitoshi Shirachi*, \\ Jun Tanaka*, Masaya Todoroki*, and Fumitake Kamegawa*
}

\begin{abstract}
【はじめに】脛骨骨幹部骨折に対する髄内釘手術において，閉鎖的整復が困難な症例が存在する。我々 はそのような症例に対し観血的整復を行っており，今回その治療成績について報告する。【対象及び方法】 2001 年 1 月から 2010 年 12 月までの間，閉鎖性脛骨骨幹部骨折に対し，Stryker 社製 T 2 tibial nail を用 いて骨接合術を行った 65 例中，観血的整復を必要とした症例は 6 例で，術後早期に転医となった 1 例を 除く 5 例を対象とした。手術は骨折部に切開を加え骨把持鉗子にて整復位を保持し䯣内釷手術を行った。 骨癒合，骨癒合までの期間，骨癒合時の骨折部の変形について検討した。【結果】全例に骨癒合を認め，骨 癒合までの期間は 16〜25 週（平均 20.5 週），角状変形は $3^{\circ}$ 以内であった。
\end{abstract}

We report some cases of intramedullary nailing for tibial shaft fracture which is usually used for open reduction as it often cannot be applied to closed reduction. We report such cases in this paper.

Osteosynthesis was performed on a total of 65 patients to treat closed tibial shaft fractures using T2 tibial nails (Stryker, Michigan) from January 2001 to December 2010. We actively performed open reduction in six of these cases, but evaluated, only five cases in this study as one case moved to another hospital. An incision was made over the fractured point for the intramedullary nailing while maintaining the reduced position of the bone using a bone-holding forceps. Bone union as well as deformities during bone union were assessed.

Bone union was found in all five cases and took 16 to 25 weeks (average 20.5 weeks). Angular deformity was within $3^{\circ}$.

Key words : open reduction（観血的整復），tibial shaft fractures（脛骨骨幹部骨折），intramedullary nail (髄内釘)

\section{I 、はじめに}

脛骨骨幹部骨折に対する髄内釘手術は一般的となっ ているが, 髄腔拡大部での長い螺旋骨折や斜骨折では 短縮転位，角状変形，骨折部の離開などを生じやすく 閉鎖的整復が困難な症例が存在する，我々はその様な 症例に対しては観血的整復を行った後に髄内釷の挿入 をしており，今回その治療成績を報告する.

\section{II．対象および方法}

2001 年 1 月から 2010 年 12 月までの 10 年間に閉鎖
性脛骨骨幹部骨折 65 例に対して Stryker 社製 T2 Tibial nail を用いて䯣内釷手術を行った。この内，骨 折部の観血的整復を行った症例は 6 例で，手術後早期 に転医となった 1 例を除く 5 例を対象とした。性別は 男性 2 例, 女性 3 例で, 手術時年齢は 26 73 歳（平 均 52 歳), 手術後経過観察期間は 40 92 週（平均 60 週）であった。骨折部位は骨幹部近位 $1 / 3$ での骨折が 1 例，遠位 $1 / 3$ での骨折が 4 例, AO 分類では A $1: 3$ 例，B $1: 2$ 例であった.

観血的整復は骨折部直上に切開を加え，骨把持鉗子 を挿入して直視下㧍よび透視下に整復を確認した（図

\footnotetext{
* 福岡徳洲会病院整形外科 Department of Orthopaedic Surgery, Fukuoka Tokushukai Medical Center, Fukuoka, Japan
} 


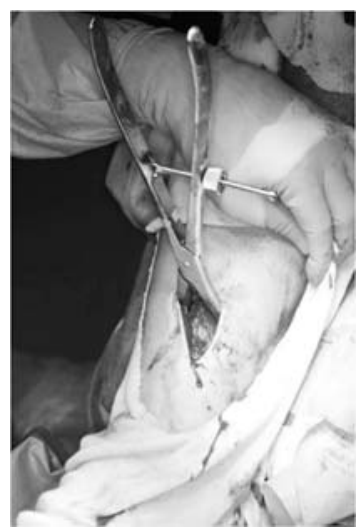

図 1 観血的整復

1).Nail の挿入は膝屈曲位で膝蓋勒帯を正中で縦切し て刺入口を作成し $1 \mathrm{~mm}$ の over reaming の後に行い 近位・遠位とも 2 本以上の interlocking screw を挿入 して static locking とした. 術後の歩行は, 部分荷重 が 3 4 週 (平均 3.4 週)，全荷重が $4 \sim 6$ 週（平均 5.6 週）であった。

これらの症例に対して, 骨癒合の有無, 骨癒合まで の期間，最終調査時の骨折部の変形角度を計測した。 骨癒合の判定は正, 側面単純 X 線像にて 3 つの皮質 骨部分で連続性が認められた時点とした。

\section{III. 結 果}

骨癒合は全例で得られており, 骨癒合までの期間は, 術後 1 年 6 力月当院を受診していなかった 1 例を除い た 5 例で 16〜25 週（平均 20.5 週）であった。最終調 査時の変形角度は平均 $1.4^{\circ}$ の後方凸変形, 平均 $0.6^{\circ}$
表 1 全症例の結果

\begin{tabular}{c|c|c|c|c|c|c}
\hline \hline & AO 分類 & 骨折部位 & 骨癒合 & 癒合期間 & 前方凸(度) & 外反(度) \\
\hline 63歳 女性 & B 1 & 近位 $1 / 3$ & 有 & 16 週 & 0 & 2 \\
\hline 36 歳 男性 & A 1 & 遠位 $1 / 3$ & 有 & 25 週 & 0 & 1 \\
\hline 73 歳 女性 & B 1 & 遠位 $1 / 3$ & 有 & 20 週 & -2 & -1 \\
\hline 62歳 男性 & A 1 & 遠位 $1 / 3$ & 有 & 21 週 & -2 & 3 \\
\hline 26歳 男性 & A 1 & 遠位 $1 / 3$ & 有 & - & -3 & -2 \\
\hline & & & & & & \\
\hline 平均 & & & $5 / 5$ & 20.5 週 & -1.4 & 0.6 \\
\hline
\end{tabular}

の外反変形を認めた (表 1$)$. 感染やコンパートメン 卜症候群などの合併症を起こした症例はなく，最終調 査時に疼痛を訴えた症例もなかった。

\section{IV．症例供覧}

<症例 $1>63$ 歳，女性. 現病歴：階段を踏み外して受 傷した．脛骨骨幹部近位 $1 / 3$ に AO 分類 type B 1 の 第 3 骨片を伴う斜骨折および腓骨近位端骨折を認め た。受傷後 12 日目に観血的整復を行い髄内釘手術を 行った。術後 3 週より部分荷重歩行，5週より全荷重 歩行を行い，術後 15 週の単純 X 線像にて骨癒合と判 定した。術後 40 週の最終調査時, 前方凸变形 $0^{\circ}$, 外 反変形 $2^{\circ}$ であり疼痛なく独歩可能であった（図 2 ). <症例 $2>36$ 歳, 男性. 現病歴: $50 \mathrm{cc}$ バイク走行中 にトラックと衝突し受傷した。脛骨骨幹部遠位 $1 / 3$ に AO 分類 type A 1 の螺旋骨折および腓骨遠位端骨折 を認めた。受傷後 8 日目に観血的整復を行い髄内釘手 術を行った，腓骨は脛骨を整復した時点で，短縮転位 が整復されていたため K-wireでの髄内釷固定とし

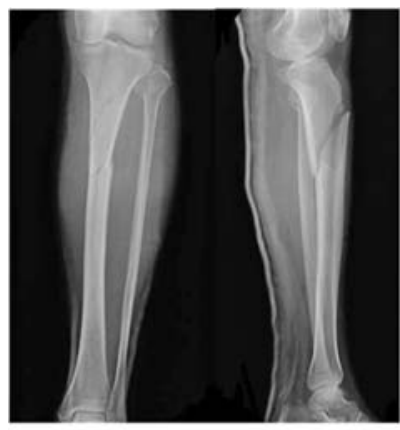

受傷時

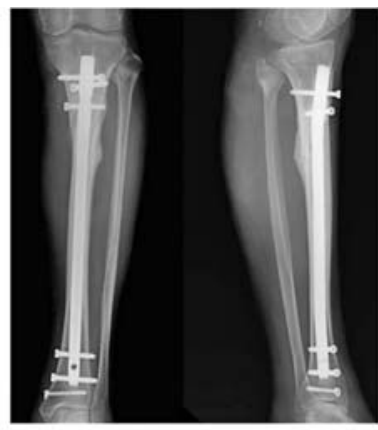

術後 15 週

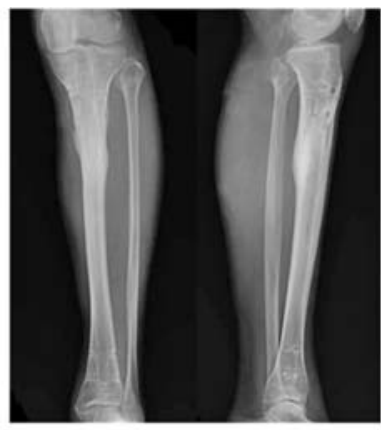

術後 40 週

図 2 症例 163 歳 女性 


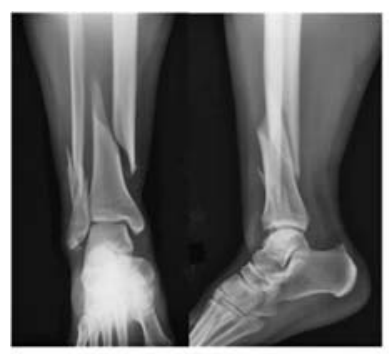

受傷時

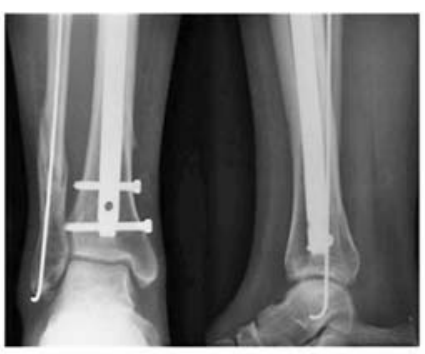

術後 15 週

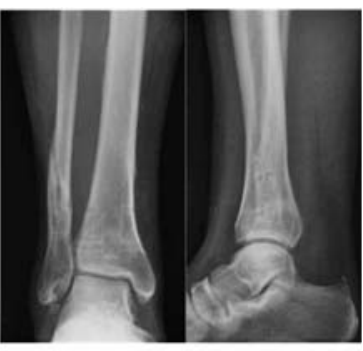

術後 40 週

図 3 症例 236 歳 男性

た. 術後 3 週より部分荷重歩行， 6 週より全荷重歩行 を行い, 術後 25 週の単純 X 線像にて骨瘠合と判定し た。術後 56 週の最終調查時, 前方凸変形 $0^{\circ}$, 外反変 形 $1^{\circ}$ であり疼痛なく独歩可能であった（図 3$)$.

\section{V. 考察}

脛骨骨幹部骨折に対する髄内釘手術は一般的となっ て抢り，その治療成績が数多く報告されてい $3^{13(3)(1212-14161618)}$.

髄内釘手術において閉鎖的整復に固執するあまりに 整復位が不良となることは好ましいことではない。整 復位不良例を原因とする変形癒合，遷延癒合や偽関節 例についの報告が散見される26(7) (79-11115177)。脛骨の整復 位不良は下肢アライメント異常を来たして下肢機能障 害につながる。特に脛骨骨幹部骨折における近位や遠 位 $1 / 3$ の長い螺旋骨折，斜骨折では短縮転位，角状変 形，骨折部の離開などを生じやすく閉鎖的整復が困難 な症例が存在する。その理由として髄腔径が髄内釷径 より広いこと, 膝屈曲位で行う従来の手術方法での整 復位の獲得や保持が困難なことなどが挙げられる。最 近では膝伸展位で supra patella approachで髄内釘を 挿入する手術が行われており，この手技では閉鎖的整 復もわりと容易ではあるが，まだ一部の施設で行われ ているに過ぎないまた，以前から行われている整復 補助操作として blocking screw techniqueがあるが, これは適切な螺子刺入部範囲が狭いこと, 髄内釘と干 渉して髄内釷挿入障害となること，無理な髄内釬挿 入により術中骨折の危険性が増加すること，螺子位 置の変更により生じた骨孔での骨折の危険性が増加 することなどが報告されており必ずしも容易な手技で はない5(7) (10).

我々は骨折治療の最優先項目は整復位の獲得である
と考えており，閉鎖的整復が困難な症例に対して観血 的整復を行った後に䯣内釷手術を行っている，直視下 に骨折部を確認するため手技は簡便であり短時間で正 確な整復位を獲得することができる。

一方，骨折部を展開することで骨瘾合にとって不利 な状況となることが危惧されるが4，皮切を小さくし 骨膜の更なる剥離を行わないことで骨折周囲組織の損 傷をできるだけ少なくするように注意している，諸家 の脛骨骨幹部骨折に対する髄内釗手術の報告と比較す ると，閉鎖骨折に対する閉鎖性髄内釷手術では癒合率

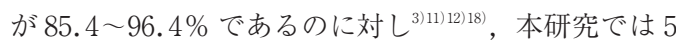
例と少数ではあるが全例骨癒合していた。骨癒合期間 に関しては14.2 20.3 週であるのに対し本研究では 16 25 週（平均 20.5 週）と閉鎖性手術と比べても遜

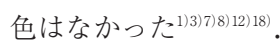

また，一般的に骨癒合時の許容される変形について は角状变形は $5 \sim 10^{\circ}$ 未満, 内・外反変形は $5^{\circ}$ 未満 とされているが, 本研究での最終調查時の変形角度は 平均 $1.4^{\circ}$ の後方凸変形, 平均 $0.6^{\circ}$ の外反変形とほほ 正常な解剖学的整復位が獲得できていた.

多くの報告者が述べているように可能な限り閉鎖的 に髄内釷手術を行うのは当然であるが，本研究で報告 したような海綿骨が豊富である髄腔拡大部での観血的 整復は骨癒合に与える悪影響は少ないのではないかと 考えられた。

\section{VI. 結語}

1）観血的整復を行った 5 例の脛骨骨幹部骨折に対す る髄内釬手術について報告した。

2）脛骨の変形癒合は下肢の機能障害を引き起こす危 険性があり，正確な整復が必要である。

3）骨癒合・骨癒合期間ともに観血的整復による不利 
益は生じなかった.

\section{参 考 文 献}

1）鎮西伸顕ら：ストライカー社製 $\mathrm{T} 2$ ネイルを用いた脛骨 骨幹部骨折の治療経験. 中部整災誌, 53(1)：189190, 2010.

2）蜂谷将史ら：下腿骨骨折に対する観血的整復術の髄内釘 の適応と限界。骨折，10:233-238，1988.

3）本多一宏ら：下腿骨折に対する髄内釘の治療成績．骨 折, 22(1) : 315-318, 2000.

4）系満盛憲：髄内釘実施上の基本とその展開。骨折，14： 143-148, 1992.

5）神田章男ら：髄内釘固定の整復補助操作に扮ける Kirschner wire を使用した blocker pin の有用性. 骨折, $29(3): 603-607,2007$.

6）柏葉光宏ら：脛骨骨幹部骨折の髄内釬治療における骨癒 合因子の検討。骨折，29(1)：132-135，2007.

7）川口謙一ら：脛骨遠位骨幹部骨折の治療経験。骨折，31 (3) : 633-636, 2009.

8）川上直明ら：脛骨骨幹部骨折に対する䯣内釘固定術の治 療経験．中四整会誌，23(1)：59-64，2011.

9）川上幸雄ら：脛骨遠位部開放骨折に対する Poller screw 併用二次的䯣内釘固定の治療経験。骨折，26(2)：695-
698, 2004.

10）久保田迅是ら：脛骨遠位骨幹部骨折に対する䯣内釘固定 法の治療成績。骨折，29(1)：144-146，2007.

11）丸野秀人，内倉長造，里見和彦：下腿骨骨幹部骨折の予 後不良因子の検討。東日本整災会誌，16(2)：289-292, 2004.

12）小川健一ら：脛骨骨幹部骨折に対する髄内釘固定，骨 折, 30(1): 164-167, 2008.

13）重信浩一ら：下肢骨折に対する髄内釬手術の経験。中四 整会誌，7(1)：59-62，1995.

14）白濱正博ら：長管骨骨幹部骨折に対する軸圧負荷機能を 持つ䯣内釘による治療. 整形外科, 55(11)：1410-1413, 2004.

15）冨田文久，田崎悌史：T2 脛骨ネイルによる脛骨遠位端 骨折治療の有用性と問題点. 北海道整形外科外傷研究会 会誌, $20: 19-23,2003$.

16）土田敏典，尾島朋宏，山城輝久：脛骨遠位部骨折に対す 万髄内釷固定術。医療，51(10)：471-475，1997.

17）内野正隆ら：大腿骨・下腿骨骨折遷延癒合に対する低出 力超音波パルス治療の検討。骨折，31(3)：592-598, 2009.

18）浦川 浩ら：髄内釘を用いた脛骨骨幹部骨折の治療成 績. 骨折, 28(4)：703-706，2006. 